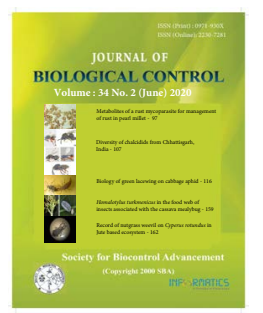

Research Article

\title{
Impact of Trichogramma release regimes and combination with mass trapping on sugarcane internode borer (Chilo sacchariphagus indicus) management
}

\author{
M. PRABAKARAN ${ }^{1,4 *}$, S. SITHANANTHAM ${ }^{2}$, K.P. SANJAYAN ${ }^{1}$, R. KRISHNA MOHAN ${ }^{3}$, S. PARIMALARANGAN ${ }^{3}$ \\ and E. SURENDRA NAIDU ${ }^{3}$ \\ ${ }^{1}$ Guru Nanak College, Department of Advanced Zoology \& Biotechnology, Velachery Main Road, Chennai-600 042, Tamil Nadu, India \\ ${ }^{2}$ Sun Agro Biotech Research Centre (SABRC), 3/1798, Main Road, Madanandapuram, Chennai 600125, Tamil Nadu, India \\ ${ }^{3}$ Natems Sugars Private limited, Nindra Cross, Koppedu-517587, Chittoor Dist., Andhra Pradesh. India \\ ${ }^{4}$ Presently with Laksitha Agro Biotech, Chennai-600125 \\ *Corresponding author E-mail: prabakaranbio07@gmail.com
}

\begin{abstract}
Large area study on the impact of six versus ten releases of the biocontrol agent, Trichogramma chilonis, besides large plot assessment of ten releases with and without mass trapping (by pheromone traps) for eco-safe management of the sugarcane internode borer (INB) - Chilo sacchariphagus indicus Kapur were undertaken in Natems Sugar factory area, Koppedu Taluk, Chittoor District, Andhra Pradesh, South India. In 2017-18, a large contiguous sugarcane crop area of 400 hectares received six releases of T. chilonis (as Tricho cards (a) 5cc.ha/release) in alternate weeks during 5-7 months age of crop, followed by four additional releases during 8-9 months age (totalling ten releases) in 40 hectares area, besides assigning a no release block of 40 hectares in adjacent area. Harvest-time sampling in each treatment block showed that the INB distribution (per cent canes infested) was $80 \%$ in control (no release) block, while it was 42 and $27 \%$, respectively, for six and ten releases. The INB intensity (per cent internodes infested) was also more $(6.2 \%)$ in control block whereas it was only $3.2 \%$ and $1.5 \%$, in the two respective release regimes. Based on these results the cost-effectiveness of both the regimes was ascertained. In 2018-19, the impact of ten releases of T. chilonis (@5cc/hectare /release) versus same regime plus mass trapping (@25 pheromone traps/ha) was compared in large plots (each of $2.0 \mathrm{ha}$ ) along with an untreated control plot. Harvest-time samples showed that INB distribution was $70.3 \%$ in control block, compared to $48.3 \%$ in Trichogramma release block versus $19.8 \%$ in block combining Trichogramma and mass trapping. The respective INB intensity was $6.04 \%, 4.04 \%$ and $2.17 \%$ while the estimated cane yields were $81.0,86.2$ and 92.5 tons/ha, respectively. The cost: benefit ratios for Trichogramma release with and without mass trapping were comparable, so confirming that both are cost-effective alternatives to chemical insecticide use in sugarcane agro-ecosystems.
\end{abstract}

KEY WORDS: Chilo sacchariphagus indicus, Internode borer, mass trapping, sugarcane, Trichogramma releases

(Article chronicle: Received: 07-01-2020; Revised: 21-05-2020; Accepted: 02-06-2020)

\section{INTRODUCTION}

Biocontrol of sugarcane borers with inundative releases of Trichogramma has been widely recommended globally (Sithanantham et al., 2013). The scope to optimize the release regimes of Trichogramma chilonis Ishii based on local severity levels of the sugarcane internode borer (Chilo sacchariphagus indicus Kapur) has been illustrated in a sugar mill R\&D network project in South India (Sithanantham et al., 2015). Bhavani et al. (2016) demonstrated the potential for combining Trichogramma releases and pheromone-based mass trapping for eco-safe and economical management of sugarcane early shoot borer (Chilo infuscatellus Snellen) and internode borer, Chilo sacchariphagus indicus Kapur in South India. More recent on-station studies in Bihar by Hari Chand et al. (2018) have shown that season-long mass trapping could reduce the incidence levels of three sugarcane borers (viz. Chilo infuscatellus Snellen, Chilo auricilius Dudgeon and Scirpophaga exceptalis Walker) by a range of 48-57 percent, resulting in an increase in cane yield by 5.63 tonnes/ha

The present study included large area impact validation of two regimes of Trichogramma releases for INB biocontrol, besides large block assessment of relative benefit of Trichogramma release alone versus with pheromone-based mass trapping in Natems Sugar Mill area of Andhra Pradesh, India. 


\section{Large area impact validation for two release regimes of Trichogramma chilonis}

The impact validation study was undertaken in 400 hectares of contiguous crop area with the cane variety V.46 under Natems Sugars, Koppedu, Chittoor, Andhra Pradesh during 2017-18. During 5-7months crop age, six releases were made in alternate weeks (T1), while four additional releases (totalling ten releases) during 8-9 months age in same crop but limited to 40 hectares area (T2), while another 40 hectare crop in the adjacent village was kept as control(no release)(T3). The releases of T. chilonis @ $5 \mathrm{cc} / \mathrm{ha}$, were made with Tricho cards stapled on underside of leaves (see plate1) across forty equi-distant release points per hectare.
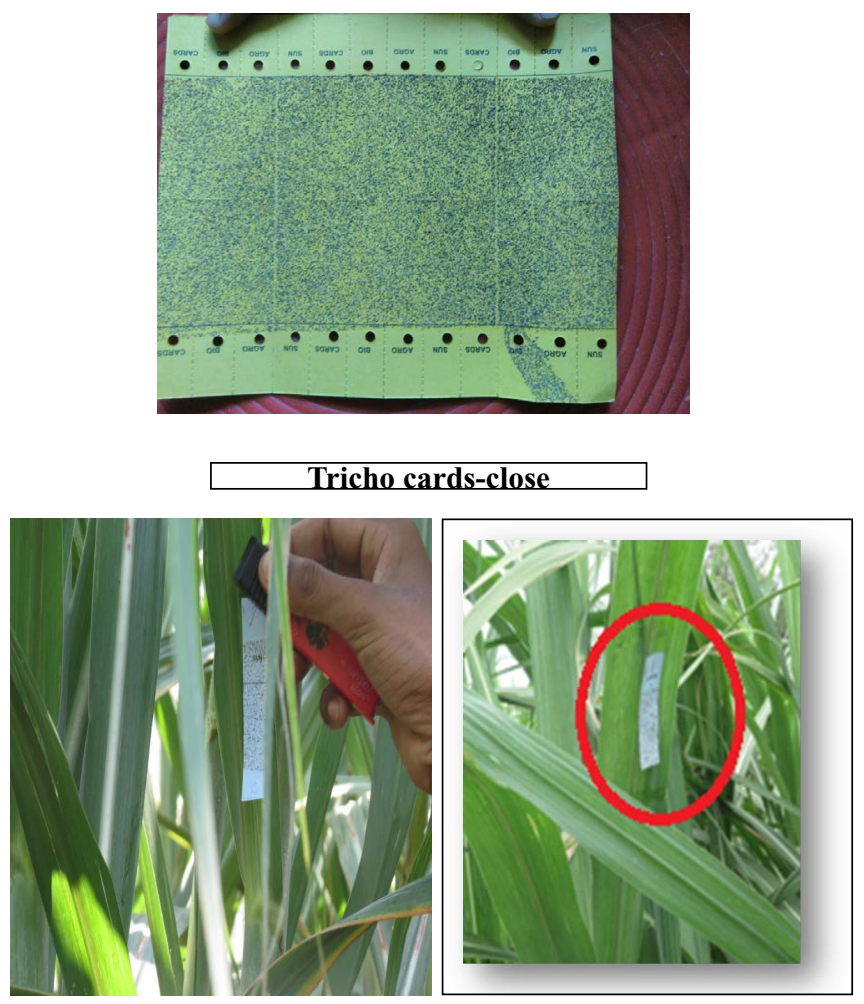

\section{Tricho card releasing in field}

Plate 1. Tricho cards-close up and fixing them in sugarcane leaves

The sugarcane crops were grown as per recommended agronomic practices except that no insecticide was applied during the study period. Data on the Internode Borer (INB) incidence on cane basis (distribution) and on internode basis (intensity) were collected at harvest time sampling by back-tracking of crop age (months) based on recording the positions of the borer infestation symptom (bore hole) in different internode positions from the cane base (see Plate 2).

\section{Internode position \& crop age at INB attack}

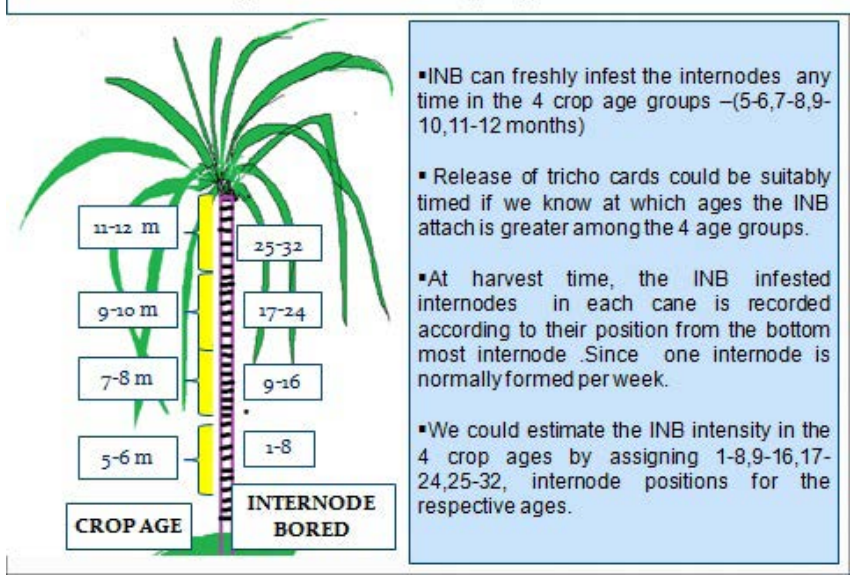

Plate 2. Chart of crop age-wise position of internodes in backtracking INB infestation

This methodology obviates the cumbersome recording of borer infestation in the standing crop and based on the robust assumption of each successive internode representing a week in the phenology, as described by Sithanantham et al. (2017). For each treatment, there were eight random samples (replicates) of one cent (40sq.m) area each, both for recording the borer infestation as well as the number of millable canes at harvest, besides the cane weight from a bundle of fifty randomly chosen canes per sample, which enabled estimating the cane yield per hectare. The area-wide cane yields could not be recorded due to the machine harvesting system and rigid weighing procedures in tractor loads adopted at factorylevel.

\section{Large plot impact of Trichogramma alone and in com- bination with mass trapping}

During 2018-19 season, the impact validation of Trichogramma releases, both alone and in combination with mass trapping (with pheromone traps) during 5-9 month crop stage was undertaken in a seven hectare farm growing same cane variety (V-46) in the same sugar factory area. The following three treatments were imposed in blocks of 2 hectare each, with 0.25 ha of buffer area for all treatment blocks.

T1- Ten releases (weekly) of T. chilonis (@5cc/ha per release

T2- Same as T1 plus mass trapping (25 pheromone traps/ha)

T3- Untreated control block 
PRABAKARAN et al.

The traps used were of Delta Plus design along rubber septa as pheromone luring (see Plate3).

\section{Delta trap dimensions}
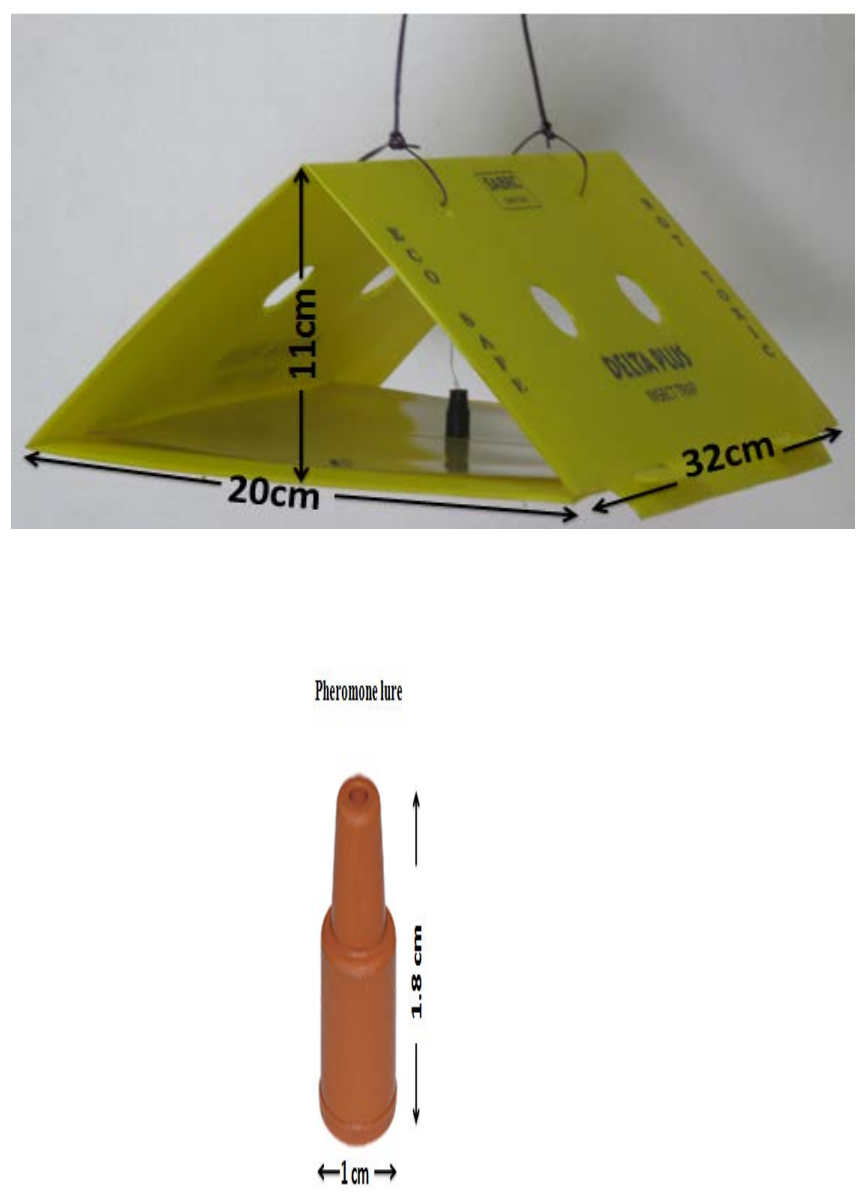

Plate 3. Delta trap and rubber septa lure used in mass trapping

The superiority of this trap design over the alternative trap types like funnel trap and water basin trap has been confirmed by Sithanantham et.al. (2019). Twenty five pheromone traps were deployed per hectare, based on the justifications given by Bhavani et.al. (2016). The mass-reared T. chilonis and pheromone traps (Delta Plus) with rubber septa lures (loaded with $3 \mathrm{mg}$ INB pheromone) were availed from Sun Agro Biotech Research Centre, Chennai .

Data on the borer infestation severity and cane yield were recorded as in the previous study. The data were subject to Analysis of Variance (ANOVA) as per Gomez and Gomez (1983).
Table 1. Relative impact of two release regimes of Trichogramma chilonis on INB incidence

\begin{tabular}{|c|c|c|}
\hline Treatments & $\begin{array}{c}\text { INB distribution } \\
\text { (Cane basis) (\%) }\end{array}$ & $\begin{array}{c}\text { INB intensity } \\
\text { (nternode basis } \\
(\%)\end{array}$ \\
\hline T1 & 42.0 & 3.3 \\
\hline & & \\
\hline T2 & 27.2 & 1.52 \\
\hline T3 & 80.2 & 6.26 \\
\hline Significance & $* *$ & $* *$ \\
\hline CD (p=0.05) & 18.07 & 2.09 \\
\hline
\end{tabular}

\section{RESULTS AND DISCUSSION}

\section{Large-area impact study of two Trichogramma release regimes}

The differences between treatments in INB distribution and intensity were significant (Table1.).

The INB distribution (per cent canes damaged) was about $80 \%$ in block without release of Trico cards (T3) compared to about $42 \%$ under six releases (T2) and about $27 \%$ under ten releases, the reduction in INB distributions due to six and ten releases being 50 and 69 per cent respectively, over the borer level in control treatment. While the INB intensity (per cent internodes damaged) in no release (T3) block was 6.26 percent, it was 3.33 and 1.52 percent respectively for six and ten release blocks, the respective reduction being about 48 and 76 percent. Based on their expected positive impacts on cane yield, it was ascertained that both regimes were costeffective.

The INB intensity (percent internodes bored) pattern among the four crop ages was mostly consistent among the three treatments compared (Fig.1)

While the no release (T3) fields showed about 4.0, 6.1, 6.5 and 2.8 per cent INB intensity during 5-6, 7-8, 9-10 and 11-12 months age of crop, the respective INB intensity for the two release regimes (T1 and T2 both) were consistently less at all four crop ages, also indicating the cumulative effect over the crop ages. 


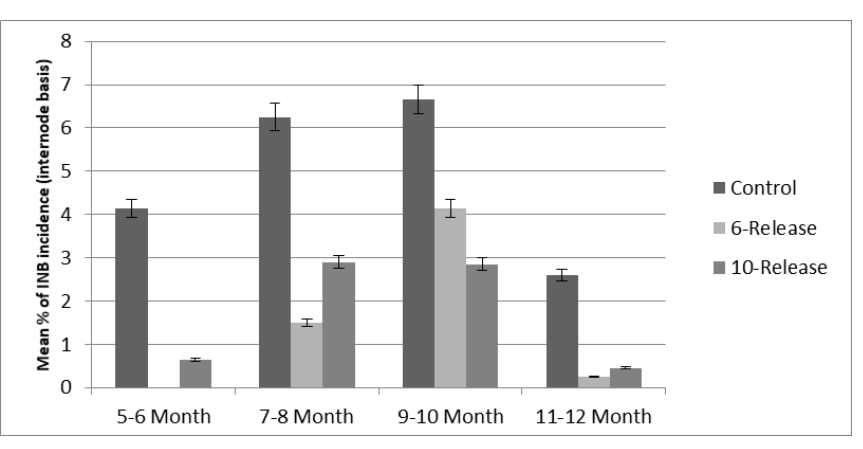

Fig 1. Crop age-wise INB incidence pattern for the three treatments compared

\section{Results of impact by combination of Trichogramma} releases and mass trapping

The differences among the three treatments were significant for both INB distribution (cane basis \%) and intensity (internode basis \%), besides for sugarcane yield (Table 2).

Table 2. Summary of results on internode borer incidence and sugarcane yield

\begin{tabular}{|c|c|c|c|}
\hline Treatments & $\begin{array}{c}\text { INB } \\
\text { distribution } \\
\text { (Cane basis) } \\
\text { (\%) }\end{array}$ & $\begin{array}{c}\text { INB intensity } \\
\text { (Internode } \\
\text { basis (\%) }\end{array}$ & $\begin{array}{c}\text { Sugarcane } \\
\text { yield } \\
\text { (ha) }\end{array}$ \\
\hline T1 & 48.3 & 4.04 & 86.2 \\
\hline T2 & 19.8 & 2.17 & 92.6 \\
\hline T3 & 70.3 & 6.04 & 81.0 \\
\hline Significance & $* *$ & $* *$ & $* *$ \\
\hline & & & \\
\hline CD (p=0.05) & 4.17 & 0.47 & 2.50 \\
\hline
\end{tabular}

**: Significant at $\mathrm{p}=0.01$

The results showed that the INB distribution (cane basis percent) was reduced from $70.3 \%$ in control block to $48.3 \%$ in Trichogramma release block, while the block with Trichogramma plus pheromone trapping showed the least incidence $(19.8 \%)$. This accounted for reduction due to Trichogramma alone by $31 \%$, versus $72 \%$ when combined with pheromone trapping. The INB intensity was found to be reduced from $6.04 \%$, to $4.04 \%$ and $2.17 \%$, respectively.

While the cane yield was 81.0 tons/ha in no release (control) plot, the respective yield in the two comparison treatments being 86.2 tons/ha and 92.5 tons/ha. Based on the prevailing cost for Trichogramma releases being Rs: 3,000/ ha. (10x5cc@ Rs.60/cc) and pheromone trapping cost estimated as Rs: 3,000/ha (25 xRs120/trap), the combined treatments cost was reckoned as Rs.6, 000/ha. Based on the minimum support price of cane at Rs.2000/tonne, the benefit for Trichogramma release alone was Rs.10, 400 (5.2 tons@, Rs.2000/ton), and when combined with mass trapping it was Rs.23, 000 (11.5tons @Rs2000/ton). The respective costbenefit ratios were 1:3.5 and 1:3.8. The benefit due to mass tapping alone was estimated as Rs.12, 600 (6.3tonxRs2000/ ton), the cost: benefit ratio of such component alone being reckoned as 1:4.2.

While the large area release impact study confirmed the benefits of both six and ten release regimes for Trichogramma, the consistent reduction in INB distribution and intensity levels for the two release regimes, besides the impressive cost: benefit ratios $(1: 7$ to $1: 11)$ are in conformity with findings from Trichogramma release regime comparisons for six versus 12 or 24 releases made in Sakthi Sugars area in Tamilnadu by Geetha et al. (2009).

The observed large block impact of Trichogramma releases alone and in combination with mass trapping in significantly reducing the distribution and intensity of INB along with concurrent cane yield improvements are also in conformity with similar impact observed for both INB and Early shoot borer (ESB) together in another zone of Andhra Pradesh by Bhavani et al., (2016) which estimated the combined benefit to be about 11tonnes/ha (96.42 tonnes/ ha versus 85.50 tonnes/ha in control block), and pheromone trapping alone contributing to yield increase by 4.0 tonnes/ha.

\section{CONCLUSIONS}

Based on the present large area impact validation of Trichogramma release regimes and the synergy effect of combining Trichogramma with mass trapping for INB, the benefits of Trichogramma-based biocontrol combined with pheromone-based mass trapping could be widely promoted by more sugar factory R\&D networking, so to impart a cascading effect on awareness and adoption among sugarcane farmers as more cost-effective and eco-safe alternative to chemical insecticide use and so conserve sugarcane ecosystem biodiversity.

\section{ACKNOWLEDGEMENTS}

Grateful appreciations are extended to the management of Natems Sugars Pvt Ltd, Koppedu, and Andhra Pradesh and to their R\&D team for field data collection support extended by Mr. Suresh, Cane officer. The liberal assistance provided by colleagues of Sun Agro Biotech Research Centre, is also thankfully acknowledged. 
PRABAKARAN et al.

\section{REFERENCES}

Bhavani B, Visalakshi M, Bharathalakshmi M. Veerabhadra Rao K. 2016. Integrated management of sugarcane borer complex through mass trapping with pheromone lures and biological controls. STC Agric Nat Resour. 2(6):13-17.

Geetha N, Shekinah, ED, Rakkiyappan P. 2009. Comparative impact of release frequency of Trichogramma chilonis Ishii against Chilo sacchariphagus indicus (Kapur) in sugarcane. J Biol Control 23(4): 343-351.

Gomez KA, Gomez AA. 1983. Statistical procedures for agricultural research. John Wiley \& sons, NewYork, USA. 680pp.

Hari Chand, Ranju Kumari, Minnatulah MD, Sudhir Paswan. 2018. Management of borers complex through pheromone traps in sugarcane agro-ecosystem of Bihar. Int J Curr Microbiol App Sci. 7: 158-167.

Sithanantham, S, Geetha, N, Baitha A, Jalali S K. 2013. Utility of Trichogramma for biocontrol of sugarcane borers. pp-271-300. In: Sithanantham S, Chandish R Ballal, Jalali SK, Bhaktavatsalam N (Eds.). Biological control of Insects pests using egg parasitoids. Springer
Publishers London. https://doi.org/10.1007/978-81322-1181-5_12

Sithanantham S, Kandasamy R, Prabakaran M, Judy S, Manikandan KR. 2015. Multifaceted factory-level R\&D model to locally maximize the economic benefit of ecofriendly sugarcane borer management methods. SISSTA Sugar J. 45:37-49.

Sithanantham S, Judy S, Thamaraichelvi C, Prabakaran M. 2017. Time-saving sampling methodology for harvest stage assessment of crop age-wise internode borer infestation at sugar factory-level. SISSTA Sugar J. 47: 196-206.

Sithanantham S, Prabakaran M, Bhavani B, Jhansi K, Vijayaprasd P, Babu V, Punnarao VV, Kannanraja N. 2019. Multi-location test of alternative pheromone trap designs for water basin traps for early shoot borer in south India. Sugar Tech. 22(1): 98-104. https://doi. org/10.1007/s12355-019-00744-7 